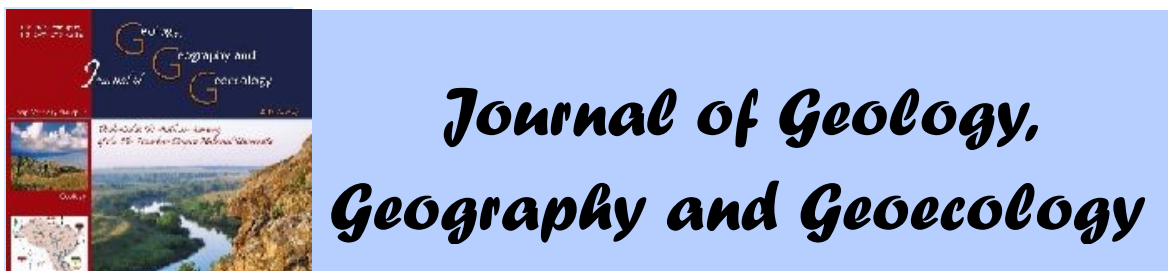

Journal home page: geology-dnu-dp.ua
ISSN 2617-2909 (print)

ISSN 2617-2119 (online)

Journ.Geol.Geograph.

Geoecology,

27(2),316-322

doi: $10.15421 / 111855$

Narjess Karoui-Yaakoub, Moncef Said Mtimet

Semeh Bejaoui, Bienvenido Martínez-Navarro

Journ.Geol.Geograph.Geoecology, 27(2), 316-322

\title{
Paleoenvironmental reconstruction of the Pleistocene site of Oued Sarrat (Northwestern Tunisia) using mineralogical and geochemical data
}

\author{
Narjess Karoui-Yaakoub ${ }^{1}$, Moncef Said Mtimet $^{1}$, Semeh Bejaoui ${ }^{1}$, Bienvenido Martínez-Navarro ${ }^{2,3,4}$ \\ ${ }^{1}$ Département des Sciences de la Terre, Faculté des Sciences de Bizerte, Université de Carthage, Jarzouna, 7021 \\ Bizerte, Tunisia,narjess1999@yahoo.fr \\ ${ }^{2}$ ICREA, Barcelona, Spain \\ ${ }^{3}$ Institut Català de Paleoecologia Humana i Evolució Social. Campus Sescelades URV (Edifici W3), 43007 - \\ Tarragona, Spain \\ ${ }^{4}$ Àrea de Prehistoria, Universitat Rovira i Virgili (URV). Avda. Catalunya, 35. 43002 - Tarragona, Spain
}

Received 07.05.2018;

Received in revised form 27.07.2018;

Accepted 01.06.2018

Abstract. The mineralogical and geochemical analyses of Pleistocene sediments and mollusks shells (gastropods and bivalves) from the archaeopaleontological site of Oued Sarrat (Tejerouine, NW Tunisia) permitted us to determine the paleoenvironmental conditions and to reconstruct the local depositional environment during the Middle and Late Pleistocene. The mineralogical cortege of the sediments, for all the analyzed samples, records the characteristics of a mixture of silica and calcite dominance with a small fraction of gypsum and aragonite. The mineralogical analyses of all mollusk species reflect a cortege dominated by aragonite, associated with low amounts of calcite, silica, hematite and goethite. We consider that the dominance of aragonite indicates that the tests have not yet or little undergone mineralogical transformations linked to the phenomena of fossilization, as evidenced by the absence or low calcite content. On the other hand, the low percentages of silica, goethite and hematite are probably related to the existence of impurities and sediments trapped in lodges, or adhered to the shell surface. The mineralogical data confirm a composition dominated by calcium carbonates, expressed by high contents of $\mathrm{CaO}$ and $\mathrm{CO}_{2}$, reflecting a chemical test of organisms' development in continental environment.This kind of environment is characterized by the absence of $\mathrm{MgO}$, which is usually present in the organisms' tests developed in marine environment. However, the contents of $\mathrm{SiO}_{2}, \mathrm{Fe}_{2} \mathrm{O}_{3}, \mathrm{Al}_{2} \mathrm{O}_{3}$ are related, as it was reported during the mineralogical study, to the lithological impurities trapped mainly in the lodges of helicides. Mineralogical and geochemical data tracing, carried out on sediments and tests, converge to deduce the establishment of paleoenvironment attributable to fluvial deposition of sufficiently high energy where the ultrafine fractions of clay minerals are remarkably lacking. The absence of indicators of marine chemistry such as magnesium in sediments and in the tests of organisms confirms almost total contribution of the continental meteoric water without marine influence. Such environment, however, is affected by intermittent episodes of aridity as attested by the presence of evaporate minerals such as gypsumand aragonite.

Key words:Environment reconstruction, Geochemistry, Mineralogy, Pleistocene, Oued Sarrat, Tunisia

\section{лео-екологічн реконструкція плейстоценового місцезн ходження уд рр т (пів- нічно-з хідний уніс) з використ нням мінер логічних т геохімічних д них}

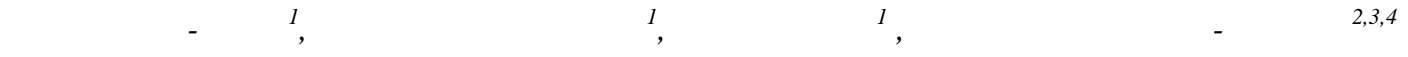

1 еп рт мент н укв - ерре, фк культетн нк ізер, рф генський університет, рзун, 7021 ізерт , yнic,narjess1999@yahoo.fr

${ }^{2}$ ICREA, рселон, сп нія

m лонський інститут $n$ леоекологї̈ людини $m$ соці льної еволюції. CaтриsSesceladesURV (EdificiW3), 43007 - $\quad$ рр гон, сп ні

4 оісторичн обл сть, ніверситет овір і ергілі ( ). Avda $m$ лонія, 35.43002 - рр гон, сп нія

нот ція. мінер логічному т геохімічному н ліз х плейстоценових ос дів т череп шок молюсків (черевоногих т двостулкових) 3 рхеоп леонтологічного об'єкт уд- рр т ( ейчеруін, івнічний уніс) дозволили визн чити п леоекологічні умови н вколишнього середовищ т реконструюв ти лок льне ос дове середовище протягом середнього т пізнього плейстоцену. інер логічн послідовність відкл дів для всіх н лізов них зр зків фіксує х р ктеристики суміші кремне- 
зему т домінуючого к льциту із незн чною кількістю гіпсу т р гоніту. інер логічний н ліз усіх видів молюсків відобр ж є послідовність, в якій домінують р гоніт, пов'яз ний з низькою кількістю к льциту, кремнезему, гем титу т гетиту.

и вв ж ємо, що домінув ння р гоніту вк зує н те, що досліджені зр зки ще не з зн ли бо з зн ли незн чних мінер логічних перетворень, пов'яз них з явищ ми літифік ції, про що свідч ть відсутність бо низький вміст к льциту. іншого боку, низький вміст кремнезему, гетиту і гем титу, ймовірно пов'яз ний з існув нням змішув ння і з хоплення ос дів у 6 з льному ш рі, бо прикріплення до поверхні оболонки череп шки. інер логічні д ні підтвердили скл д, в якому перев ж ють к рбон ти к льцію, що відбив ється високим вмістом $\mathrm{CaO}$ і $\mathrm{CO}_{2}$ т відобр ж є хімічний скл д орг нізмів, які розвив лися у континент льних умов х. ей вид середовищ $\mathrm{x}$ р ктеризується відсутністю $\mathrm{MgO}$, який з звич й присутній у досліджув них орг нізм х, що розвив лися у морському середовищі. дн к вміст $\mathrm{SiO}_{2}, \mathrm{Fe}_{2} \mathrm{O} 3, \mathrm{Al}_{2} \mathrm{O}_{3} \in$ пов'яз ним, як вст новлено мінер логічними дослідженнями, літологічно неоднорідними суміш ми в норк х геліцидів. осліджені мінер логічні і геохімічні д ні, які отрим ні по ос д х і зр зк х, свідч ть про вст новлення особливостей п леосередовищ у зв'язку із флюві льними поток мидост тньо високої енергії, в яких суттєво бр кує н дтонких фр кцій глинястих мінер лів. ідсутність у ос д х і зр зк х орг нізмів індик торів утворення їх у морському середовищі, т ких як м гній, підтверджують м йже повне привнесення континент льної тмосферної води без впливу морської. тім, т ки умови екологічного середовищ зумовлені впливом періодичних епізодів ридиз ції клім ту, про що свідчить присутність т кого ев поритового мінер лу як гіпс.

лючові слов : охорон н вколищнього середовищ, геохімія, мінер логія, плейстоцен, уніс

1. Introduction. The archaeopaleontological site of Oued Sarrat (Tejerouine, NW Tunisia) was discovered in 2014 and a large amount of vertebrate data was added for North Africa, with a special discovery of the aurochs Bos primigenius (MartínezNavarro et al., 2014) and Canis othmanii (Amri et al., 2017). The Quaternary continental molluscs from this site were studied for the first time by Karoui-Yaakoub et al. (2016). Here we present mineralogical and geochemical data obtained from the Pleistocene sediments and molluscs tests (gastro- pods and bivalves) of Oued Sarrat with the aim of reconstructiing the Middle and Late Pleistocene paleoenvironments of the Oued Sarrat basin.

2. Geographical and geological setting. Oued Sarrat is located in the northwestern part of Tunisia, $10 \mathrm{~km}$ southwestwards from the Tajerouine (Fig.1). This region belongs to an intermediate zone between the Central and the Northern Atlas of Tunisia, with diapirs and rifts. It is dominated by folded structures interspersed with rift basins corresponding to the kalaa el Khasba and Rouhia Depression.

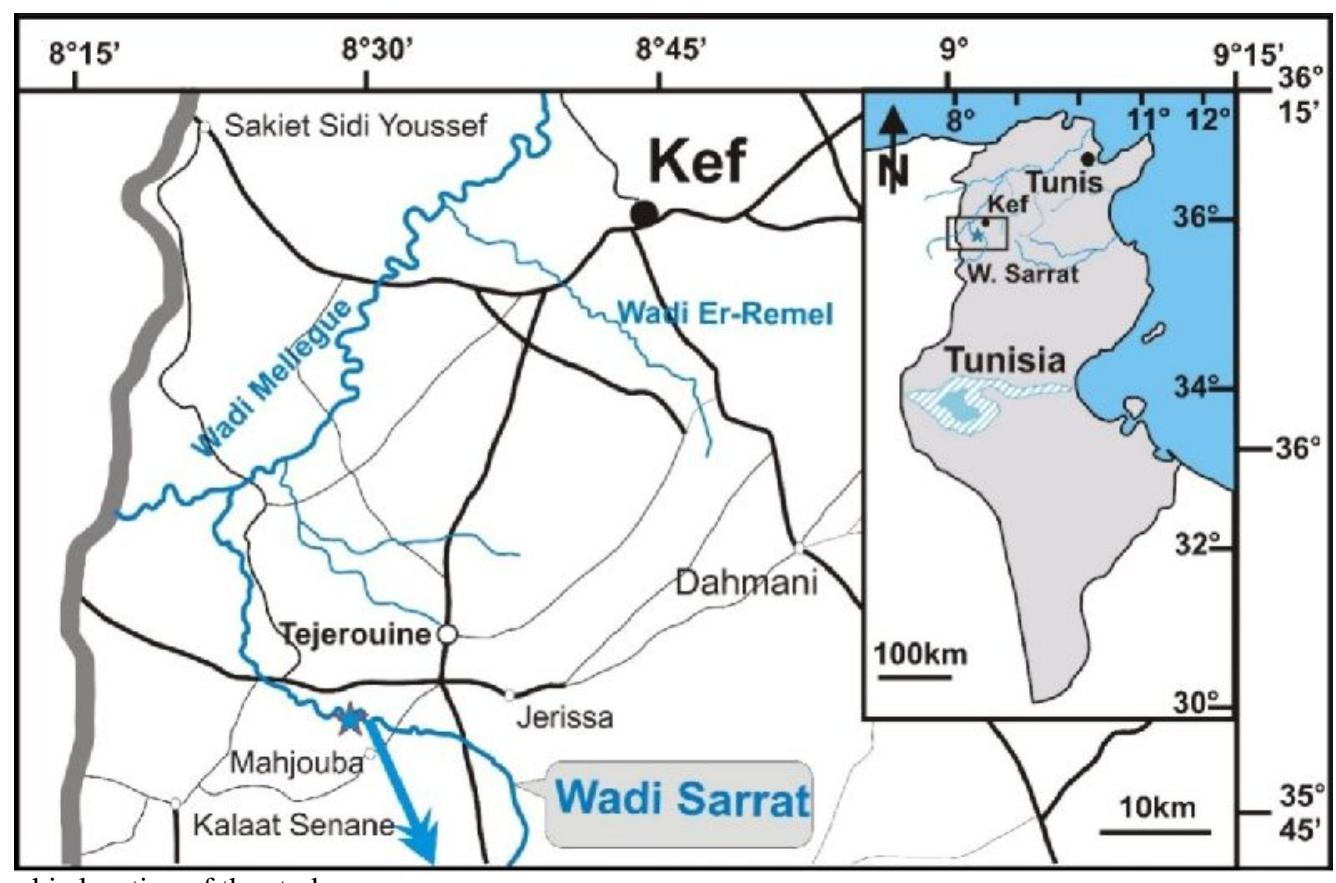

Fig. 1. Geographic location of the study area

The Pleistocene series of Oued Sarrat are composed of three units (Fig. 2). At the base, there are four meters of gray-black marl (OS1 and OS2). This layer is rich on vertebrate fauna, in particular Bos primigenius and Canis othmanii.This level is dated as beginning of the Middle Pleistocene ( 0.7 Ma) by magnetostratigraphy and the presence of fossil remains of rodents (Martínez-Navarro et al., 2014; Mtimet et al., 2014). It should be noted that these marls are rich in invertebrate fossils, specifically gastropods and bivalves.

Above, a second clay level $(2 \mathrm{~m})$ overcomes the first black level unconformably. It is less compact and dated to the Late Pleistocene (OS3). This 
level is rich in invertebrate fossils - bivalves (Unio ravoisieri) and gastropods (Xerosecta cespitum, Cernuella virgata, Eobania vermiculata, Helix melanostoma, Sphincterochila baetica, Rumina decollata) (see Amri, 2014; Bejaoui, 2014; Martinez-Na-varro et al., 2014; Mtimet et al., 2014; Karoui-Yaakoub et al., 2016; Amri et al., 2017).

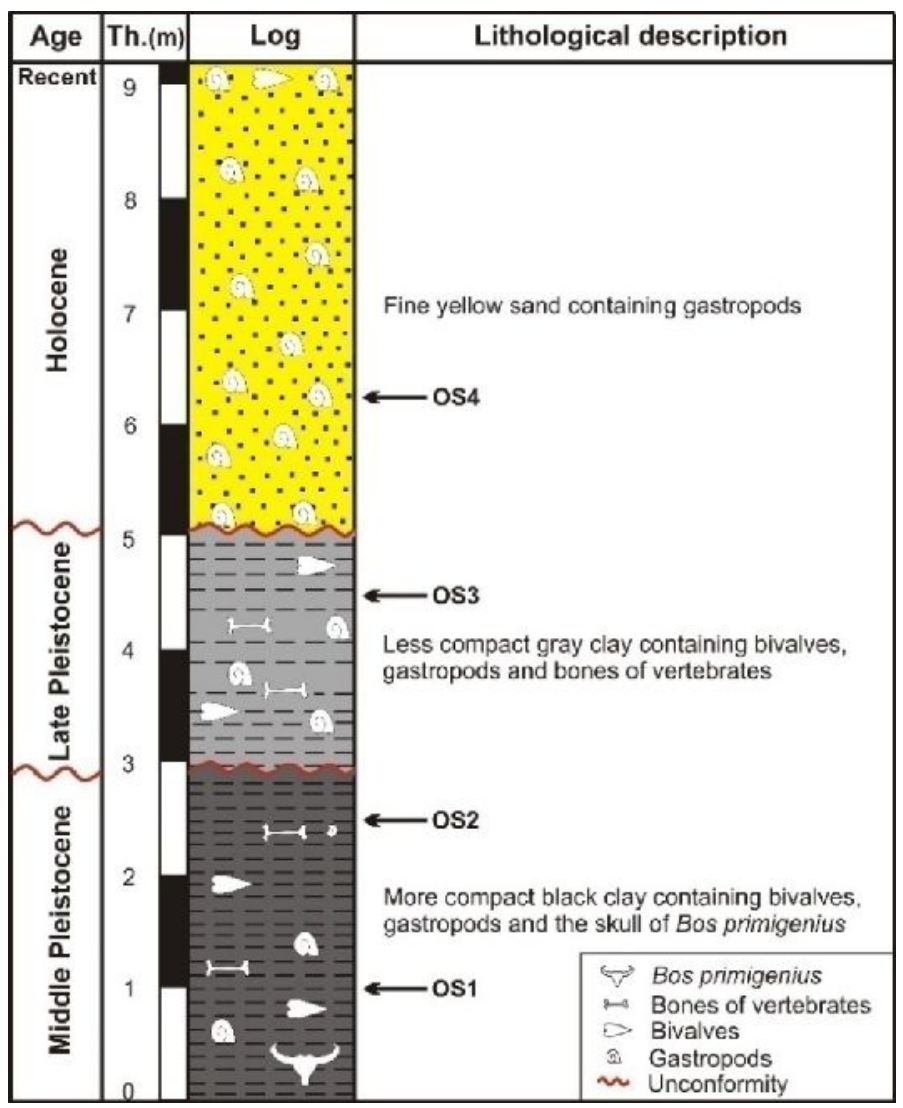

Fig. 2. Stratigraphic synthesis of the Oued sarrat series (in Karoui-Yaakoub et al., 20116)

At the top of the section (Fig. 3), a second disconformity is registered by the deposition of the third level, yellow to slightly brownish marl about 4 $\mathrm{m}$ in thickness (OS4). It yielded gastropods of Holocene age (Martínez-Navarro et al., 2014; KarouiYaakoub et al., 2016).

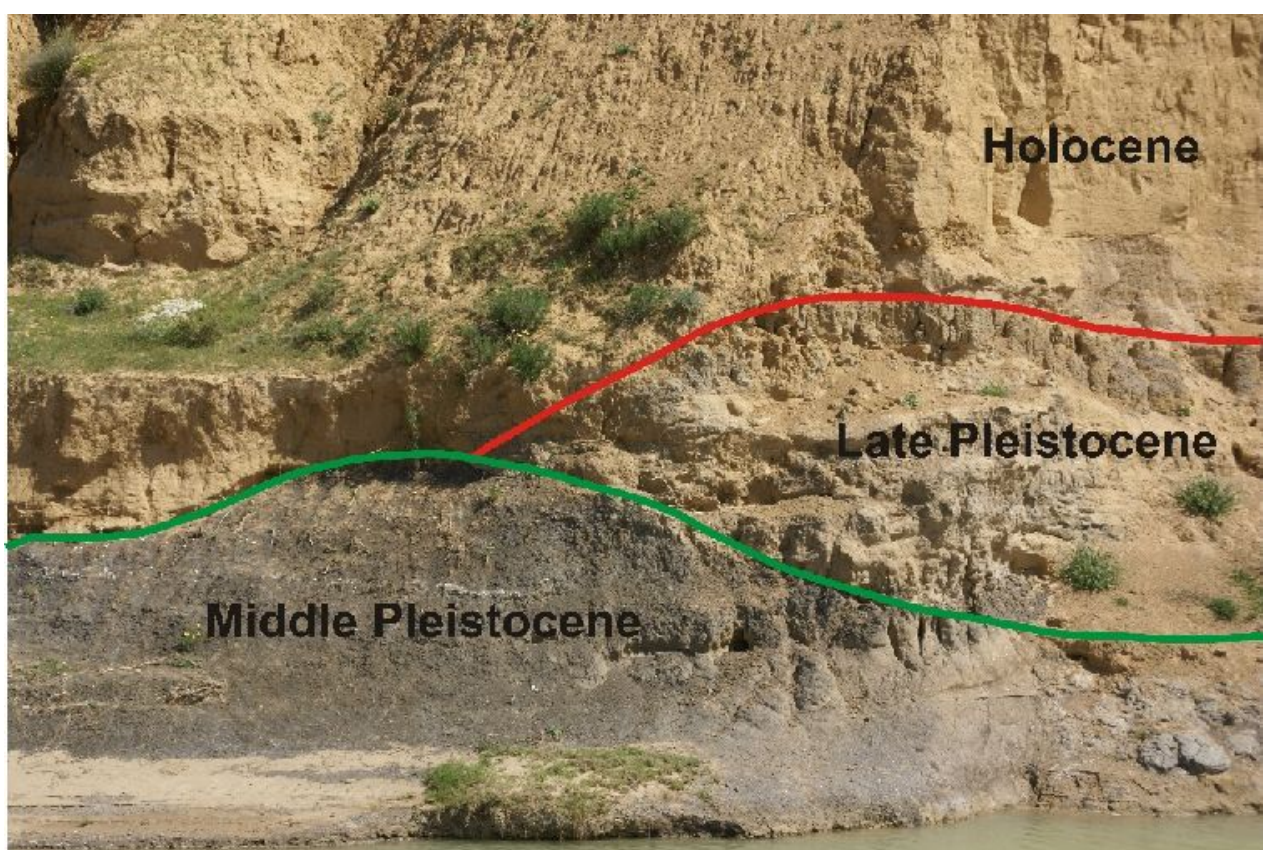

Fig. 3. The unconformity between the Middle and Late Pleistocene and between the Late Pleistocene and Holocene (MartínezNavarro et al., 2014) 
3. Materials and methods. Shells of gastropods and bivalves were sampled following the described Middle and Late Pleistocene stratigraphic series, which is outcropped on both sides of the Oued Sarrat.

The mineralogical and geochemical studies were performed on clay sediments from three levels yielding malacofauna. Two samples (OS1 and OS2) come from the Middle Pleistocene level, one sam- ple (OS3) - from the Late Pleistocene level, and another one (OS4) - from Holocene marls.

\section{Results of the study}

\subsection{Mineralogical cortege}

\subsubsection{Mineralogy on bivalves and gastropods}

The results of mineralogical analyses of all registered mollusc species reflect a cortege dominated by mineral aragonite associated with low amounts of calcite, silica, hematite and goethite (Tab. 1, Fig. 4).

Table 1. Mineralogical composition of mollusk shells of Oued sarrat

\begin{tabular}{|l|c|c|c|c|c|}
\hline & $\begin{array}{c}\text { FeO3\% } \\
\text { Hematite }\end{array}$ & $\begin{array}{c}\text { CaCO3\% } \\
\text { Aragonite }\end{array}$ & $\begin{array}{c}\text { CaCO } \% \\
\text { Calcite }\end{array}$ & $\begin{array}{c}\text { FeO(oh)\% } \\
\text { Goethite }\end{array}$ & $\begin{array}{c}\text { SiO } \% \\
\text { Quartz }\end{array}$ \\
\hline Xerosecta cespitum & $0.132 \%$ & $92.90 \%$ & 0 & 0 & $5.99 \%$ \\
\hline Cernuella virgata & $4.19 \%$ & $89.57 \%$ & 0 & 0 & $5.44 \%$ \\
\hline Eobania vermiculata & $4.70 \%$ & $84.26 \%$ & 0 & 0 & $9.97 \%$ \\
\hline Helix melanostoma & $2.34 \%$ & $74.48 \%$ & $10.54 \%$ & 0 & $6.21 \%$ \\
\hline Sphincterochila baetica & 0 & $90.89 \%$ & 0 & $7.89 \%$ & 0 \\
\hline Rumina decollata & $0.20 \%$ & $82.48 \%$ & $9.50 \%$ & 0 & 0 \\
\hline Unio ravoisieri & $0.18 \%$ & $89.33 \%$ & 0 & 0 & $4.13 \%$ \\
\hline
\end{tabular}

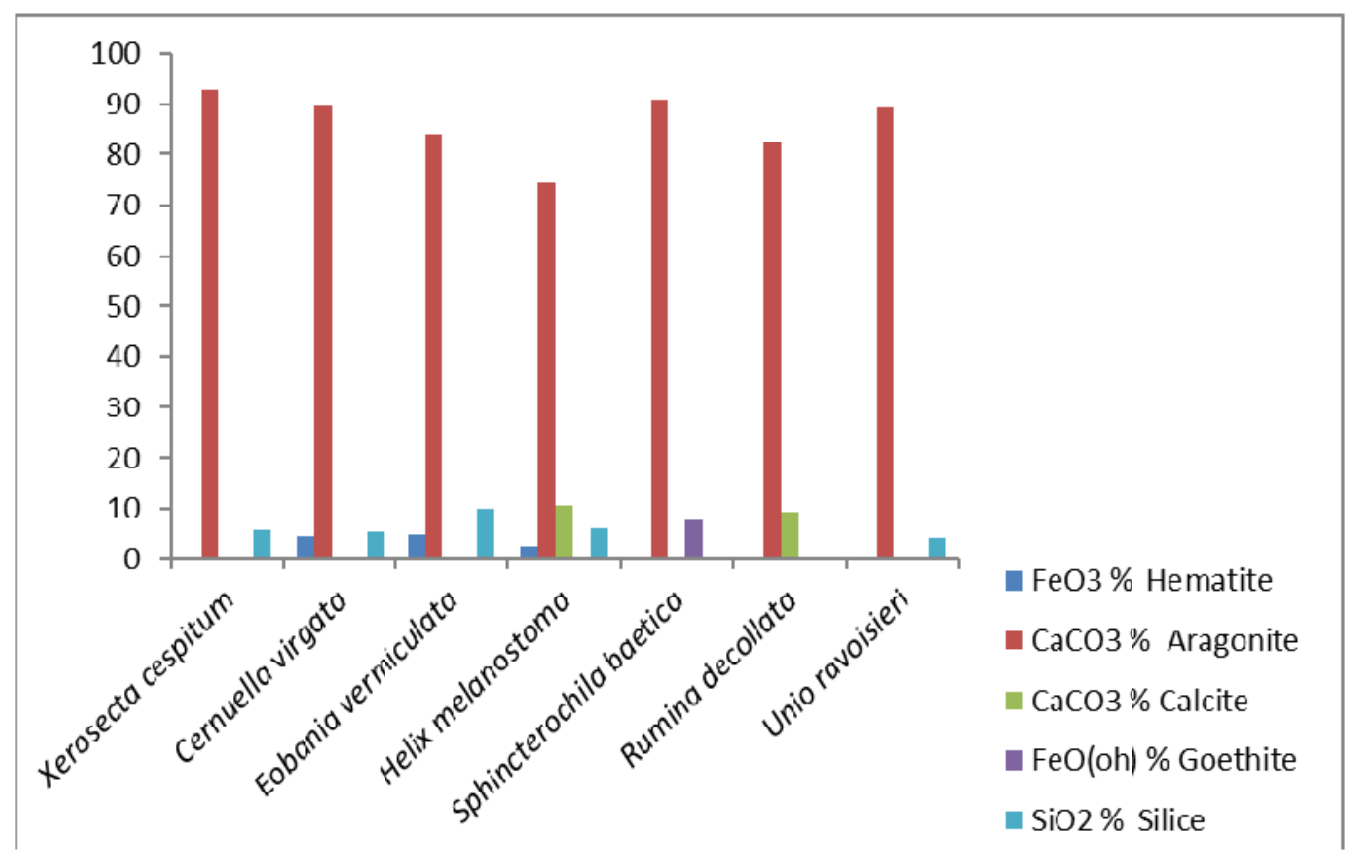

Fig. 4. Histogram of mineralogical composition of mollusk shells of Oued sarrat

We consider that the abundance of aragonite indicates that the shells have not yet undergone mineralogical transformations related to fossilization phenomena as evidenced by the absence or low content of calcite. We interpret the presence of traces of silica, goethite and hematite as due to the existence of sediment trapped in the dressing or binding to the surface of the shell. 


\subsubsection{Sediment mineralogy}

The mineralogical cortege of the sediments, for all the analyzed samples, records a mixture of silica and calcite dominance containing a small fraction of gypsum and an aragonite fraction of $11.65 \%$ in the sample OS4 (Tab.2, Fig.5). The cal- cite-silica reflects initially the characteristics of a detrital sediment in which calcite is likely related to lithoclastic fragments with low contribution of aragonitic debris, as evidenced by the low content of aragonite in the sample OS4.

Table 4. Chemical composition of clays in Oued sarrat

\begin{tabular}{|l|l|l|l|l|l|l|}
\hline & $\begin{array}{l}\text { CaCO3\% } \\
\text { Aragonite }\end{array}$ & $\begin{array}{l}\text { CaCO3\% } \\
\text { Calcite }\end{array}$ & Al203\% & FeO(oh)\% & CaSO4\% & SiO2\% \\
\hline OS1 & 0 & 40.27 & 1.12 & 7.65 & 3.57 & 36.53 \\
\hline OS2 & 0 & 43.31 & 2.94 & 5.54 & 3.66 & 29.05 \\
\hline OS3 & 0 & 51.89 & 2.78 & 7.95 & 0 & 27.20 \\
\hline OS4 & 11.65 & 34.12 & 0 & 6.65 & 0 & 18.98 \\
\hline
\end{tabular}

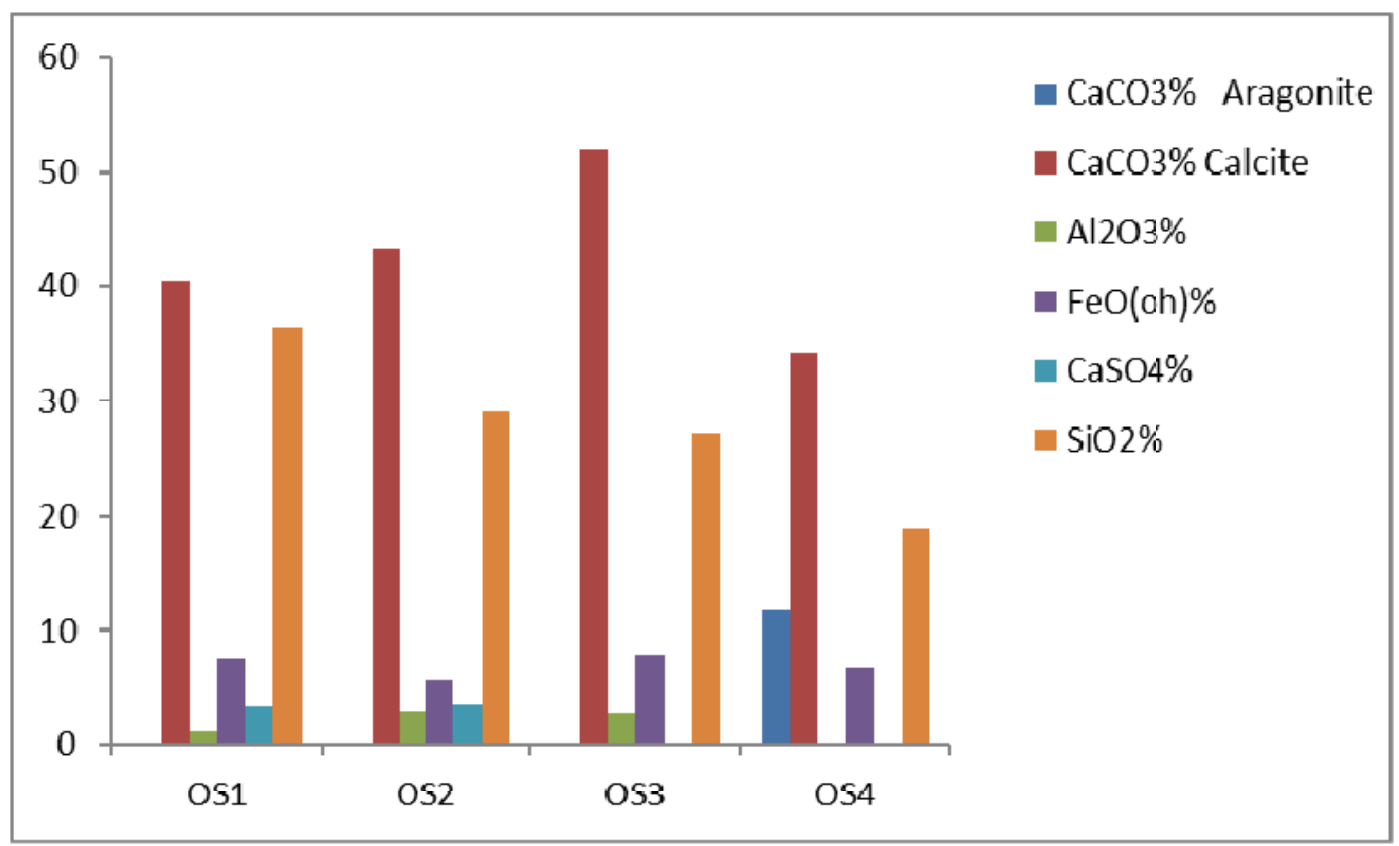

Fig. 5. Histogram of mineralogical composition of marl of Oued sarrat

\subsubsection{Interpretation}

The absence of clear clayey minerals signals in the analyzed spectra, as well as the abundance of calcified siliceous fraction, reflects a fairly highenergy fluvial environment undergoing at times of arid conditions favorable to the formation of evaporitic minerals.

\subsection{Geochemical tracing}

4.2.1. Analysis on shells of gastropods and bivalves

The results presented in Table 3 confirm the mineralogical data with a composition dominated by calcium carbonates, expressed by high contents of $\mathrm{CaO}$ and $\mathrm{CO}_{2}$. This reflects a chemical test on development of organisms in a continental environment clearly confirmed by the absence of $\mathrm{MgO}$, which is usually present in the organisms' tests

Table 3. Chemical composition of Pleistocene mollusk shells of Oued sarrat developed in a marine environment, with an $\mathrm{Mg}$ content varying from 12 to $18 \%$. However, it should be noted that in Pleistocene tests for the species Unio ravoisieri, the $\mathrm{Mg}$ content is equal to zero, although the analysis of the extant species shows that this values is equal to $2.31 \%$ (Tab.3, Fig.6). This low Mg content is far from reaching the characteristic values of completely marine species. This Mg rate could be linked to a certain ability of the species to obtain this element from the fluviatile waters. This ability indicates a possible change in the behaviour of above mentioned species. On the other hand, the contents of $\mathrm{SiO}_{2}, \mathrm{FeO}_{3}$, $\mathrm{Al}_{2} \mathrm{O}_{3}$, are also comparable, as it was reported during the mineralogical study, to the lithological impurities trapped mainly in the lodges of helicides. 


\begin{tabular}{|l|l|l|l|l|l|l|}
\cline { 2 - 8 } \multicolumn{1}{c|}{} & $\mathrm{CaO} \%$ & $\mathrm{Al203} \%$ & $\mathbf{C O 2} \%$ & $\mathrm{Fe2O3} \%$ & SiO2 \% & MgO\% \\
\cline { 2 - 8 } & Pleisto & Pleisto & Pleisto & Pleisto & Pleisto & Pleisto \\
\hline Xerosecta cespitum & 53.53 & 3.74 & 37.17 & 0.12 & 5.45 & 0 \\
\hline Cernuella virgata & 51.60 & 3.31 & 36.21 & 3.86 & 5.01 & 0 \\
\hline Eobania vermiculata & 49.21 & 3.87 & 33.61 & 4.27 & 9.05 & 0 \\
\hline Helix melanostoma & 48.84 & 1.07 & 36.95 & 4.79 & 5.73 & 0 \\
\hline Sphincterochila baetica & 52.29 & 3.33 & 36.72 & 6.88 & 0.00 & 0 \\
\hline Rumina decollata & 56.16 & 1.31 & 42.38 & 0.16 & 0.00 & 0 \\
\hline Unio ravoisieri & 52.50 & 5.05 & 34.65 & 3.66 & 0.00 & 0 \\
\hline
\end{tabular}

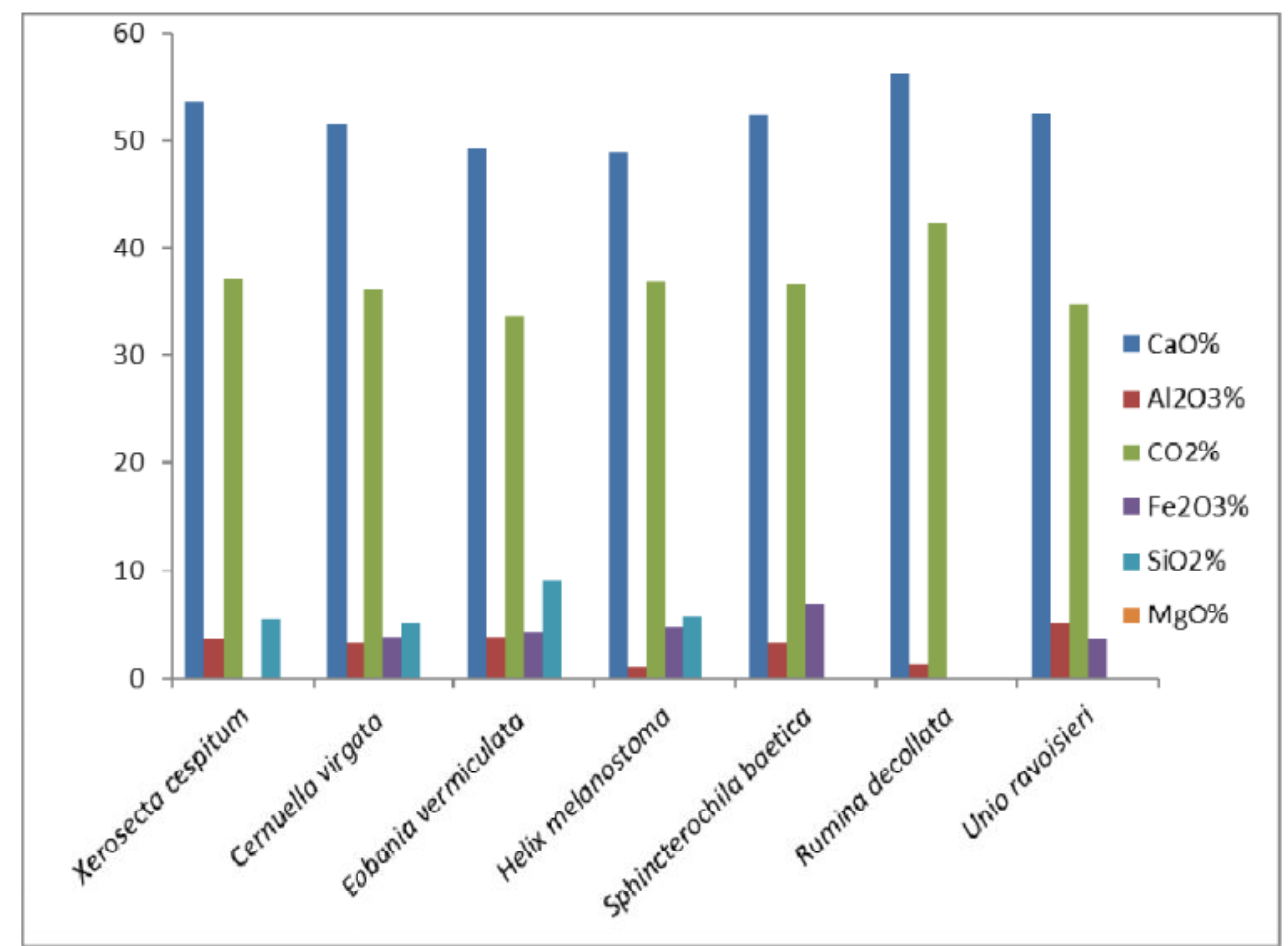

Fig. 6. Histogram of chemical composition of Pleistocene mollusk shells of Oued sarrat

\subsubsection{Sedimentological analysis}

The results presented in Table 4 reflect the original sand-calcitic and detrital sediments exceeding $90 \%$ for this fraction. Coupled with very low proportions of $\mathrm{Al}_{2} \mathrm{O}_{3}$, about $3 \%$, all data allow us to assume a fluvial environment where the water win- nowing seems to be unfavorable to the sedimentation of the ultrafine fraction of the clayey minerals. The continental chemistry is demonstrated by the absence of magnesium in all analyzed sediments $(\mathrm{MgO}=0$; Tab. 4, Fig. 7)

Table 4. Chemical composition of clays in Oued sarrat

\begin{tabular}{|l|l|l|l|l|l|l|l|}
\cline { 2 - 8 } \multicolumn{1}{c|}{} & CaO \% & Al2O3 \% & CO2 \% & Fe2O3 \% & SO3 \% & SiO2 \% & MgO\% \\
\hline OS1 & 35.85 & 0.85 & 26.96 & 5.17 & 2.14 & 27.49 & 0 \\
\hline OS2 & 35.38 & 2.94 & 26.87 & 4.84 & 1.63 & 27.05 & 0 \\
\hline OS3 & 35.64 & 3.51 & 26.78 & 8.10 & & 25.25 & 0 \\
\hline OS4 & 41.66 & & 32.68 & 5.98 & & 18.98 & 0 \\
\hline
\end{tabular}




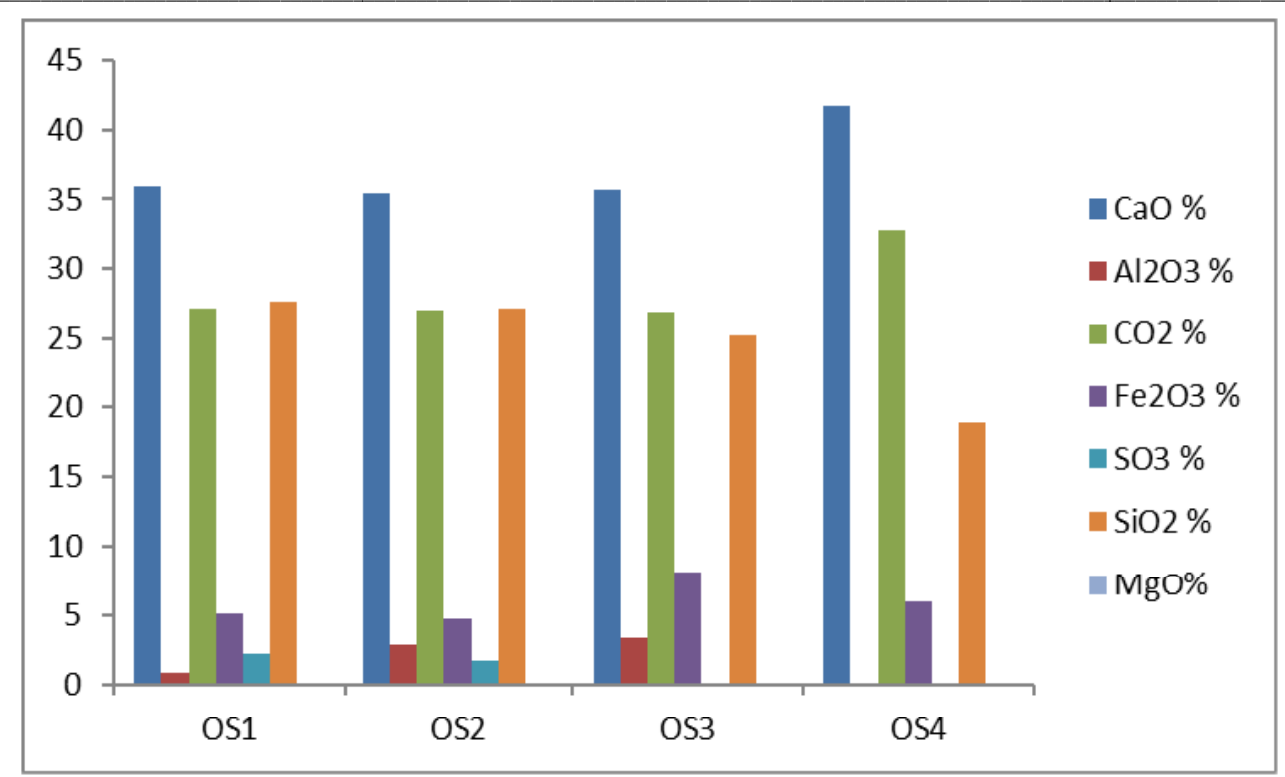

Fig.7. Histogram of chemical composition of clays in Oued sarrat

\subsection{Interpretation of mineralogical and geo- chemical data}

Mineralogical and geochemical data tracing, carried out on sediments and tests, allow us to conclude the establishment of a paleoenvironment attributable to fluvial deposition of sufficiently high energy where the ultrafine fraction of clayey minerals is remarkably lacking. The absence of indicators of marine chemistry, such as magnesium, in sediments and in the molluscs' tests confirms the almost total contribution of the continental meteoric waters without marine influence. Such environment, however, is affected by intermittent episodes of aridity as evidenced by the presence of evaporates such as gypsum.

\section{Conclusion}

Mineralogical and geochemical analyses confirm previously obtained paleoecological results (Martinez-Navarro et al., 2014; Karoui-Yaakoub et al., 2016; Amri et al., 2017). The depositional environment was definitely neither marine nor lagoonal, but rather fluvial due to continental meteoric waters in a hot climate.

The Oued Sarrat site is dated in time frame from the Middle to the Late Pleistocene, a landscape covered with swamp and forest, or even shallow freshwater lake. The latter was powered by channels and, certainly, around the lake there inhabited abundant different large mammalian species together with other small vertebrates and invertebrates that were probably consumed for human survival.

\section{References}

Amri, L., 2014.Etude paléontologique des grands mammifères quaternaires d'Oued Sarrat (Nord-
Ouest de la Tunisie). International Master Thesis in QUATERNARY AND PREHISTORY [Unpublished], $101 \mathrm{p}$.

Amri, L., Bartolini Lucenti, S., Mtimet, M.S., KarouiYaakoub, N., Ros-Montoya, S., Espigares, M.P., Boughdiri, M., Bel Haj Ali, N., MartínezNavarro, B.,2017.Canis othmanii sp. nov. (Carnivora, Canidae) from the early Middle Pleistocene site of Wadi Sarrat (Tunisia). Comptes Rendus Palevol, 16(7), 774-782. http://dx.doi.org/10.1016/j.crpv.2017.05.004

Bejaoui, S., 2014.Les mollusques continentaux d'Oued Sarrat (nord ouest de la Tunisie), paleoecologie et paleoenvironnement du Pleistocene. Mémoire de Master [Unpublished],103.

Karoui-Yaakoub, N., Mtimet, M.S., Bejaoui, S., Amri, L., Khalloufi, N., Ben Aissa, L., MartínezNavarro, B., 2016.Middle-to-Late Pleistocene malacofauna from the archeopaleontological site of Oued Sarrat (Tajerouine area, NW Tunisia). Arabian Journal of Geosciences, 9, 345. http://dx.doi.org/10.1007/s12517-016-2310-4

Martínez-Navarro, B., Karoui-Yaakoub, N., Oms, O., Amri, L., López-García, J.M., Zeräi, K., Blain, H.A., Mtimet, M.S., Espigares, M.P., Ben Haj Ali, N., Ros-Montoya, S., Boughdiri, M., Agustí, J., Khayati-Ammar, H., Maalaoui, K., Maahmoudi, O.K., Sala, R., Hawas, R., Palmqvist, P., 2014.The early Middle Pleistocene archeopaleontological site of Oued Sarrat (Tunisia) and the earliest record of Bos primigenius. Quaternary Science Reviews. 90, 37-46. http://10.1016/j.quascirev.2014.02.016

Mtimet, M.S., Karoui-Yaakoub, N., López-García, J.M.,Blain, H.A., Agustí, J.,Amri, L.,MartínezNavarro, B.,2014.The early Middle Pleistocene microvertebrate assemblage from Wadi Sarrat (Tunisia). In: XXX (ed.), XVII World UISPP Congress 2014 Burgos, 1-7 September. Volume of abstracts, p. 100-10. 